\title{
Samuel Daniel and Anne Clifford, Countess of Pembroke, Dorset, and Montgomery
}

\section{Albert Hartshorne F.S.A.}

To cite this article: Albert Hartshorne F.S.A. (1899) Samuel Daniel and Anne Clifford, Countess of Pembroke, Dorset, and Montgomery, Archaeological Journal, 56:1, 187-210, DOI: 10.1080/00665983.1899.10852819

To link to this article: http://dx.doi.org/10.1080/00665983.1899.10852819

册 Published online: 16 Jul 2014.

Submit your article to this journal $\asymp$

Џ Article views: 2

Q View related articles 5 
To face page $18 \%$.

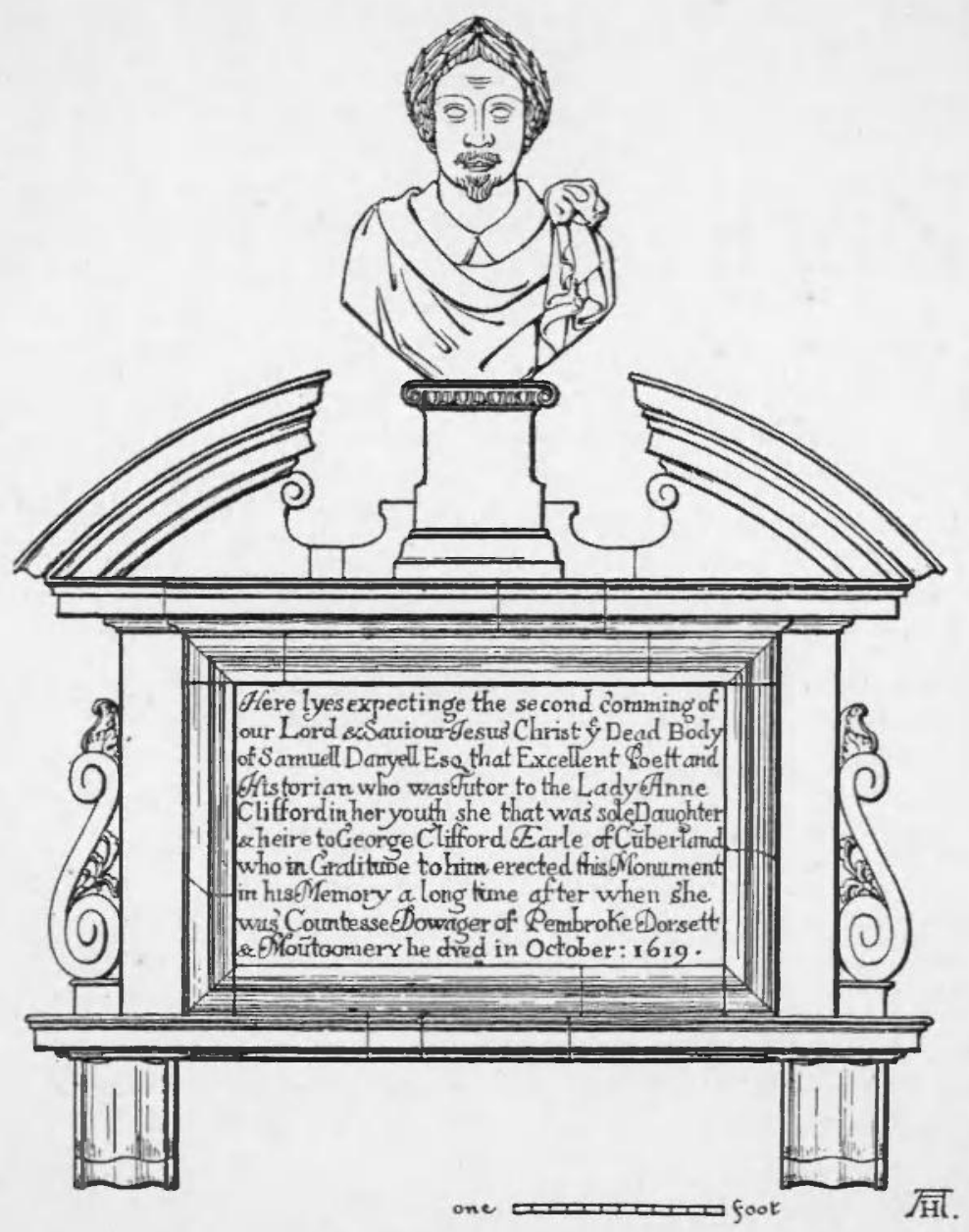

MUNOMENT OF SAYULL DANIEL IN BECEINGTON CHORCH 
SAMUEL DANIEL AND ANNE CLIFFORD, COUNTESS OF PEMBROKE, DORSET, AND MONTGOMERY.

By ALBERT HARTSHORNE, F.S.A.

Nothing is more honourable in the history of English literature during the Elizabethan age, and up to the end of the reign of George I, than the protection which was given, and the position which was accorded, under varying conditions, to men of genius, and the friendships which they gained. Thus, to take a few notable examples, Shakespeare-who needed, indeed, no patron or protector for his deathless works - found a friend in the young Earl of Southampton; Spenser was the associate of Sir Philip Sidney, Sir Walter Raleigh, and Sir Fulke Greville; Ben Jonson was befriended by the King, by Lord Bacon, by the learned Selden, and by Camden, who sent him to Westminster ; and Samuel Daniel was taken in hand by the powerful families of Clifford, Russell, and Pembroke. Another poet, and Westminster boy, scion of a noble house-the saintly George Herbert-sought neither patron nor notice during his brief and zealous life. Cowley, again a Westminster boy, was private secretary to Henrietta Maria, and Milton served as Latin secretary to Cromwell. Dryden-"Glorious Jolın"-the great English poet par excellence, yet another old Westminster, lived for forty years among the first men of the age. Such were some of the spontaneous tributes to genius in Elizabethan times and in the seventeenth century.

In the next period "the great" Mr. Congreve was a veritable pluralist in Government places. Steele was knighted, made a captain of horse, a member of Parliament, and a commissioner of stamps; Prior and Gay became secretaries of embassies; and Addison Secretary of State.

But these high rewards were artificial and venial though grateful encouragements of literature, and not for its own sake. They were the evidences of a system of political tactics which passed away soon after the death of Queen 
Anne. For political reasons again, namely the withdrawal by Walpole of ministerial support from men of literary genius, the poets of the early Georgian era-with some brilliant exceptions, such as Pope, who had survived, with his aquiline acumen, from the older generation, and was socially independent of party, and by nature averse to open patronage-fell upon bad times. Their vices were abundant, inherited from the poets of the Restoration, but with so much of added grossness that the very name of "poet" became a term of reproach and "Grub Street hacks" a synonym for an unbridled, irregular, and servile band, turning night into day after any good luck, or living from hand to mouth on the pitiful doles of avaricious booksellers, with the occasional God-send of five guineas for a fulsome dedication. "Toil, envy, want, the patron, and the jail " wrote Dr. Johnson, in bitter remembrance of passage through deep suffering, and such was then the meed of many an unhappy, disorderly, and gifted man who, like the great moralist, could "bear privations with fortitude" but could not " taste pleasure with moderation." Their sad lot may be generally contrasted with the fortune of the poets of the illustrious Elizabethan era.

With the middle of the eighteenth century came the blessed change, when the genuine patronage of a discerning and grateful public succeeded the days of starvation, the fitful and degrading help of the patron, and the grinding of the "Curlls" and the "Osbornes" of the past. The age of intelligence had arrived; the distressful period, often vaguely classified as one of "the good old times," vanished away, and the increase in the value of literary labour, which came about nearly a century and a half ago, rapidly induced a self-respecting feeling among authors; and the high social position which was then regained has, we know, been brilliantly upheld, and with extraordinary and increasing popular support up to the present day.

In a special notice of an Elizabethan poet, his works, his patrons, and his friends, it has been thought desirable first to set down, in as few words as possible, some of the general conditions under which this branch of literature has been practised in England during three centuries and 
a half, showing it to have been successively influenced or controlled, from the middle of the sixteenth century to the present day, by the action of the court, the government, the patron, the booksellers, and the public.

In this critical age the absorbing interest of the history of English literature, and particularly that of the Elizabethan period, has been set forth by a multitude of ardent students, and with an insight, appreciation, and justice which would have astonished and delighted the ancient authors, and that might stand, if such pattern were needed, as a model to the entire literary world. Daniel, indeed, looked forward-as surely all poets with a touch of the divine afflatus rightly may-to an earthly immortality through the power of his song, as in Musophilus:-

And give our labours yet this poor delight,

That when our days do end, they are not done;

And though we die we shall not perish quite, But live two lives where others have but one.

and :-

O blessed letters! that combine in one All ages past, and make one live with all.

By you we do confer with who are gone, And the dead-living into council call :

By you th' unborn shall have communion Of what we feel, and what doth us befall.

Soul of the world Knowledge, withont thee, What hath the Earth that truly glorious is ?

Why should our pride make such a stir to be, To be forgot? What good is like to this,

To do worthy the writing, and to write Worthy the reading, and the world's delight?

His pure and modern diction, so different from the ancient style of his contemporary and friend, Spenser, is to be noticed.

In touching now upon the career and works of "the well-languaged Daniel," we shall show that the esteem in which he was held by his learned contemporaries justified him in these aspirations, and that modern critics and biographers have fully endorsed the high opinion which was formed during his lifetime of the endowments of his mind by his compeers of the spacious times of Elizabeth. His famous pupil and patron, Anne Clifford, Countess of Pembroke, must have gathered from his teaching, quite 
early in her long and eventful life. much that contributed to the development of her excellent judgment and intrepid spirit. She was, indeed, a unique and striking personality, which only England, and those times, could have produced, and who would have adorned any age. We shall duly see, and without surprise, some of the reasons why her name still sounds stirring, two centuries and a quarter after her death, throughout the counties of Cumberland and Westmoreland.

Samuel Daniel is said to have been born near Taunton in 1562. ${ }^{1}$ He is reported to have been the son of a musicmaster, of whom, however, Dr. Burney makes no mention. He was entered of Magdalen Hall, now Hertford College, in 1581 , being described as "pleb"; he remained three years, but took no degree. On quitting Oxford in his twenty-first year, he appears to have at once devoted himself to the study of poetry and philosophy, particularly the works of Italian authors, which afterwards strongly influenced his style. He is thought to have gone to France in the embassy of Lord Stafford in 1586, and it was, doubtless, his ardour in literary pursuits which took him to Italy and procured him the friendship of John Florio, the erudite author of $A$ Worlde of Wordes, first published in 1598, and who is spoken of as his brotherin-law.

Daniel's first production, at the age of 23, was a translation of Paulus Jovius's Discourse of Rare Inventions, in 1585 , and his first known volume of poetry appeared in 1592. This contains the series of fifty-seven Sonnets to Delia, which have an even and limpid flow, and were often reprinted during his life. In the same year he produced the romance called The Complaint of Rosamund, and the tragedy of Cleopatra two years later, a severe classical study. The first four books of The History of the Civil War appeared in 1595, in octave stanzas, established by Boccaccio as the Italian measure for narrative poetry. This is a long recitation of dry events, in excellent diction, but the subject is ill suited for poetic treatment.

1 He has had several biographersJohnson, Chalmers, Maunders (Biographical Treasury), MIorlev (First Sketch of En!lish Literature), Gosse
(Encyclopadia Britannica) \&c., the latest notice being by Mr. Sidney Lee in the Dictionary of National Biography. 
Now a difficulty is generally acknowledged in the bibliography of Daniel's works. The probability seems to be that in the last-named year, or in the next, 1596 , when the Lady Anne Clifford was in her seventh year, that Daniel became her tutor.' In 1599 he brought out a volume of poetical essays which included, besides The (ivil War, extended to five books, Musophilus, a general defence of learning, dedicated to his friend, Sir Fulke Greville, and a Letter from Octavia to Marcus Antonius, presented to Margaret, Countess of Cumberland. These works placed the poet at the height of his fame, and they stand as purple pieces among the somewhat dull grey of his historical narrative. In 1601 appeared Epistles to Great Personages, and in 1602 a sixth book of The Civil War. It was seemingly at this time, namely in the last year of Elizabeth, that Daniel was first particularly noticed by the court, and in consequence, it is stated, of the action of Florio. If a reason for this advance need be sought for it would rather appear that the interest of the Cliffords, the Russells, and the Sidneys, and, most of all, the poet's well acknowledged talents, then justly ensured his reconnition in the highest places.

Queen Elizabeth died at 2 A.M., March 24th, 1603, and was buried in the Abbey April 28th. Among the multitude of poetic effusions which deplored her loss, England's Mourning Garment, and Sorrowes Joy, a tribute from members of the University of Cambridge, are noteworthy. In the former, a production of Henry Chettle, a playwright of some repute, several poets, including Daniel, Chapman, Drayton, and Shakespeare, are rebuked for their silence.

The fateful and officious ride of Sir Robert Carey to the north, and the delivery of " the blue ring" and the news of his accession to King James at Holyrood, and the subsequent express from the English " Princes, Peeres, and privie Counsellors of Estate," soon set the monarch on his journey southward, leaving, for sound political reasons, the heir, Prince Henry, in Stirling Castle, under the care of the Earl of Mar, much to the chagrin of his concerning her education and by the seeming hiatus in Daniel's published works at this time. 
capricious Queen. A most eventful progress, with extraordinary display of hospitality, brought the King from Edinburgh to Berwick, Newcastle-on-Tyne, Durham, York, ${ }^{1}$ Newark, and Belvoir, to Burley-Harrington, or Burley-on-the-Hill, which was reached on Saturday, April 16th, 1603, the journey having been signalised by the dubbing of a great number of knights.

An untoward and painful incident happened at Newark. A cut-purse, in the garb of a ruffling gallant of the court, having been caught in the exercise of his arocation, was ordered by King James, in the heat of the moment, to be hung out of hand. This Oriental procedure, this sudden conjunction of northern Jedburgh Justice and mediæval Lidford Law, was much commented upon to the King's dispraise. For it implied the arbitrary seizure of justice, and men said that if one should be hung without trial why shall not another be haled to prison on no offence, or tried before he had offended!

At Burley, a large and ancient house of many periods, then the property of Sir John Harrington, Daniel appeared with a long Panegyric Congratulatory "delivered" to the King, it must be supposed in MS. only, for the monarch had hunted, according to his custom, all the way from the Earl of Rutland's at Belvoir, and after dining at Burley proceeded to "Burleigh House near Stamford town," hunting bagged hares as far as that place. Entertainment so open and profuse that one is tempted to think that the true practice of this particular English virtue is now greatly moderated, greeted the King here, at Hinchinbroke, Theobalds and the Charter House, the teeming progress ending at the Tower of London on May 11th. The royal sportsman, in his most awkward costume for such efforts, hunted a poor tame deer-the "traine" subtly made to suit the regal pace-with hounds in full cry from Stamford Hill to London.

At Burley Daniel had no doubt attached himself to the King's ever increasing retinue, and when the sovereign went on his journey towards the north to meet Anne of

1 " As the king came out of Scotland, when he lay at York, there was a strife between $\mathrm{my}$ father and my Lord Burleigh, who was then President, who should carry the sword; but it was ad.

judged on my father's side because it was his office by inheritance, and so is lineally descended on me."-Diary of Anne Clifford. 
Denmark, who with her children started from Scotland on June 20th, it is probable that Daniel formed one of the party of the Cliffords, their relations, and friends, in number about 300 , who went on their own account from London to greet the new Queen. It may here be mentioned that the only ladies of Queen Flizabeth's bedchamber whom Anne of Denmark would appoint to her service were the Countess of Harrington and the Dowager of Bedford, the latter aunt of Anne Clifford. Lucy, Countess of Bedford, and daughter of Lady Harrington, was appointed to the privy chamber.

It was at Dingley near Leicester, at Sir Thomas Griffin's, that the only child and heiress of George, Earl of Cumberland, first met the Queen who proved so faithful a friend to her. The royal parties joined at Sir George Fermor's at Easton Neston, Northamptonshire, June 27th, "where there were an infinite company of Lords and Ladies and other, that the country could scarce lodge them," says the Diary of Anne Clifford. In running only rapidly through the moving events of this particular time, and with which Daniel was so much concerned, an idea may be gathered of the feverish public excitement and wild convivial turmoil amidst which James VI of Scotland succeeded to the English throne. Indeed, so eager and pressing were the crowds that the King himself, in a kind of frenzy after tame deer and bagged hares, complained that the people hunted him! Some incidents of Anne Clifford's participation in this royal progress will be touched upon presently a little more at large. It will be noticed that the poet and the pupil made their acquaintance with the new court under the same auspicious and emotional though somewhat bewildering circumstances.

The installation of Prince Henry, and others, as Knights of the Garter having taken place July 2nd, and the Coronation of the King and Queen solemnised July 25th, progresses were made into Surrey and the south of England, as far as Wiltshire, returning through Oxfordshire; and so the autumn passed away.

1 Considering the cumbersome methods of transport, the bad condition of the roads, and the vast numbers that took part in these progresses and removals from one royal house to another, it is remarkable how rapidly the country was traversed, and how much was accomplished in a short space of time. This speaks. well for the official measures. By arrangement, each county 
To return to the poet. The license for the Globe Theatre had been granted to Shakespeare, Burbage, Heminge, Condell, and others, on May 19th, 1603. The popularity of the masque, the lineal descendant of the revels of Henry VIII's time, and which had replaced the coarse or profane mediæval mummeries - had been established in the preceding reign, and these entertainments had been brought to their highest beauty by the learning and with the bright fancy and splendid diction of Ben Jonson. It now fell to Daniel to write his first masque, The Vision of the Twelve Goddesses, for the Christmas festivities at Hampton Court, January 8th, 1604, afterwards printed with a "description dedicatory" to the lovely Lucy Harrington, Countess of Bedford. In this graceful work the goddesses appear under different representations, indicating, as the poet explains, the blessings and beauties that preserve and adorn empire and dominion, a sentiment that has been well illustrated in our own time under the happy rule of a beloved and venerable sovereign. Queen Anne chose the significant office of Pallas, or "Armed Policie," and eleven of her ladies took the other parts, the last being Tethys, indicating "Power by Sea." If there were any "Little Englanders" then, this would surely have been classified by them as a reprehensible "Jingo" parade!

Wolsey's great hall was the theatre of the entertainment, with scenery devised and arranged by Mr. Sanford, and we shall now join the brilliant be-ruffed company and see what a masque was like. The proem of the Vision was the arising of Night in black vesture set with stars, who wakes her son Somnus, sleeping in his cave, and apparelled in a transparent white vestment over black, signifying the day and the night, with sable wings, and crowned with poppies. He bears respectively a white and a black wand in his hands, and by their deft use causes the temple, with Sibylla seated therein, to become apparent. Hereupon Iris descends from a mountain at the lower end of the hall, approaches the Temple of Peace, announces the coming of the Goddesses to Sibylla, and delivers to her a "prospective," or representation, by 
which she can identify them. The "prospective" is the original of the modern illustrated "programme." The twelve fair divinities, in their proper attires, preceded by the Three Graces in silver robes, with white torches, and hand-in-hand, now descend from the mountain, three and three, and between each rank of goddesses march three torch bearers, their heads and robes decked with stars. During their descent the comets, sitting as satyrs, half hidden in the concaves of the mountain, sound a stately march. Arrived at the Temple, " consorte musicke" begins, the Three Graces standing by and singing in a most engaging manner, while the Goddesses solemnly ascend, one by one, into the Temple, are addressed in poetry by Sibylla, and present their offerings, namely, the emblems of their several conditions. Now the diviniiies return into the midst of the hall, and dance with great majesty and art, to the music of the viols and lutes, in circular, square, triangular, and other rare figures full of variety. They then place themselves in a circle, the Graces again singing to the music of the Temple, and lead out the young lords of the court to dance measures, galliards, and currantos. Thus the fair maskers merge their grave Olympian divinity with the graceful accomplishments of the courtly cavaliers in their gay and mundane costume. Finally Iris again appears and notifies the pleasure of the divine powers to depart, which, after a short dance with some pleasant changes, they accordingly do, ascending the mountain in the same order as they came down, the cornets of the graceless satyrs again sounding a march, the whole play forming a delightful excursion into realms of classic fancy. It will be noticed how cleverly Daniel adapted his scheme to the different levels of the great Gothic hall.

We have gladly taken this as a proper opportunity for giving a sketch of the scheme and character of a masque, and the more so because those by Daniel are very little known. It may be that the world has now grown too cynical, too hard and old, to appreciate the fairy-like delicacy and tender lyrical spirit of these creations. And although they have not satisfied some stern critics of a century ago, who have denounced them as "fooleries," "wretched performances," and " bungling shows," we 
make bold to suggest that the censor who is not charmed by Ben Jonson's Entertainment at Althorp, or Daniel's delicious Tethys s Festival, "put on the stage" by Inigo. Jones, must be an "arbiter elegantiarum" indeed! 1

It must have been about this time that Daniel was appointed Gentleman Extraordinary and Groom of the privy chamber to the Queen, who had great delight in his conversation and works. In 1603 he had brought out Musa, a defence of Rhyme, as against a proposed classical measure, addressed to William Herbert, Earl of Pembroke, and in 1604 he completed the Civil Wars in eight books. The masque then entitled Arcadia Reformed, and afterwards The Queen's Arcadia, was written by Daniel and produced before the Queen at Oxford- "being indeed very excellent," August 30th, 1605. In the same year appeared Certain Short Poems and the tragedy of Plilotas. On June 5th, 1610, the day following the creation of Prince Henry Prince of Wales, the masque of Tethys's Festival or "The Queen's Wake," by Daniel, was presented with great splendour at Whitehall, the "artificial part" - that is the scenery. machinery, and costume, by the great "Archetictor" Inigo Jones. Anne Clifford, then Countess of Dorset, personated the Nymph of Aire. This will be referred to again. Subsequently Daniel published in prose Collection of the History of England from Roman times to the end of the reign of Edward III, first brought out in 1613 , and again in 1618 , the year before his death.

As to the merits of the works of Samuel Daniel all the critics agree that his style is better suited for prose than measure, but both his contemporaries and his modern judges place him very high among the poets of the Elizabethan age. One of the former speaks of -

The pithy Daniel whose salt lines afford

A weighty sentence in each little word.

1 A rull idea may be formed of the rich and tantastic character of some of the dresses worn at masques, from the descriptions furnished by the authors of such plays as are given in Campion's masque at Lord Hay's Marriage on Twelfth Night, 1607, and in Ben Jon. son's masque at Lord Haddington's marriage in the sear following. This information may be supplemented by the study of the long training panoramas in grisaille on great German drinking glasses from the Forest, representing persons in dresses with odd classicial or Renaissance details, such as were never worn, to use a modern ex. pression, "off the stage"; though some of the extravagant early sevent eenth century German modes seem only fitting for "maskers" in the present sense of the word. 
The brilliant Drayton, reluctant to censure him, says -

His rhimes were smooth his metres well did close;

But yet his manner better fitted prose.

A third, again, alludes to him-

My dear sweet Daniel, sharp-conceipted, brief, Civil, seutentious, for pure accents chief.

while his friend Fitz Geoffry wrote--

Spenserum-si quis nostrum velit esse Maronem,

Tu, Daniele, mibi Naso Britannus eris.

Sin illum potius Phoobum velit esse Britannum,

Tum Daniele, mihi tu Maro noster eris.

Of modern critics Headly considered that his language was so pure that it would never become obsolete. It is, indeed, in marked contrast with the quibbles and conceits of pulpit eloquence of his time and the whimsical crotchets of other minor branches of literature. Mr. Lowell held Musophilus as "the best poem of its kind in the language," and a distinguished living authority speaks of his style as "full, easy, and stately" and that "though wanting in fire and passion, he is pre-eminent in scholarly grace and tender mournful reverie." 1

With regard to the personal history of Daniel little is known. He rented a small house and garden in Old Street, St. Luke's, and married a wife named Justina-perhaps a sister of John Florio-by whom he left no issue. His brother John, a composer of music, published an edition of Samuel's works in 1624, dedicated, on behalf of poesy and music, to Prince Charles. To this edition a portrait is prefixed. This was engraved by Thomas Cookson for an edition of the Civil Wars which appeared in 1610. There is reason for thinking that John Daniel furnished the musical scores of his brother's masques. Fuller, who lived near enough to Daniel's time to speak with accuracy, recalls his pure and high religious character-so different from that of the generality of his literary confreves-and he relates that he was used to retire for long periods in his house in Old Street for quiet communion with the muses. Here he received his friends, among them Shakespeare, Chapman, Marlowe of the "mighty line," Drayton, and Jonson, besides the

${ }^{1}$ Edmund W. Gosse in Encycloperdia Britannica, edit. 1898. 
numerous persons of position who loved the gentle man, and had themselves been touched on the lips with a live coal from the altars of Parnassus.

It seems that the poet took the remarkable stepapparently at the end of the year 1610, and but a few months after his signai success with the masque of Tethys and when only in his forty-eighth year-of retiring to Beckington, Somerset, and adopting an agricultural life. His duties of tutor to Anne Clifford must have ended with her marriage, February $27 \mathrm{th}, 1610$. Well versed as Daniel was in Virgil--his fellow-husbandman poet-Fuller considered that something more than having the Georgics by heart was desirable for success in farming, and while doubting whether classic husbandry would fit the English style, he suspected that "Mr. Daniel his fancy was too fine and sublimated to be wrought down to his private profit."

It remains a secret locked in the past whether failing health, social stress, or the uncommon diffidence he had of his own abilities caused Daniel to suddenly quit the sunny court and exchange, for instance, the privilege of hearing what Fuller calls "the wit combats" between Shakespeare and Ben Jonson, and of seeing the things "Done at the Mermaid," for the dreary even tenour of a pastoral life in remote Somerset. In his roluntary exile he retained so much affectionate regard for his pupil and her family that he called his house and small estate "Cliffords Farm," a name which has continued to the present day through all the changes of nearly three centuries. It is apparent, from some windows in situ in the south front of the present farmhouse, that there was a very small and rude dwelling here at least as early as about 1430. This would have been abandoned by Daniel when his new house was built.

This is prettily situated within a bend of the rapid river Frome, on the right bank, and exactly a mile from Beckington church, with an ascent to the Bath road, from which it is plainly seen by travellers. Apparently about a hundred and fifty years ago the place was changed from pastoral to commercial uses. Daniel's house was doubled in width and greatly lengthened, so that a large part of the original Jacobean dwelling, though in a way swallowed up, still remains at the south-east corner of 
the later building, to a height of about fourteen feet, and a width of eighteen, much as in the poet's time. As to the enlarged building forming a mill, a cutting was made to bring the stream to the further end of it, with a back-brook from it, and cloth and paper making and dyeing have been successively carried on. The Jacobean mullioned windows are walled up, another farmhouse has been fashioned out of the mediæval buildings, the machinery of the mill is dislocated, and with it the remains of the poet's house and the mill itself stand forsaken and desolate. A pictorial record is here presented of the remains of the local home of one of Somerset's best worthies.

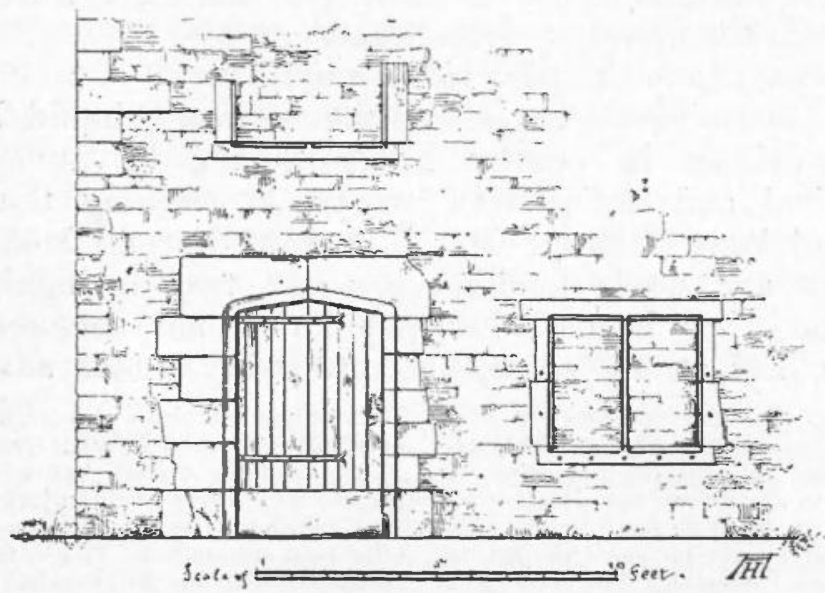

In this humble abode Daniel lived until 1619, when his refined spirit was recalled to the mercy and mystery of God. There are no indications of other entrances or windows of the poet's period, and it must be that his dead body was borne forth through the existing doorway, when his earthly part was laid to rest in the north aisle of Beckington church-as the rugged parchment register has it, under the year 1619 , with rude spelling and inverted figures, "Ano Domina Master Samuell Danuell buried the 41 of October."

Whether Daniel prospered in his uncongenial occupation we know not, but we gather with pain, from the fact that no coeval memorial marked his grave, that troublous 
days came upon him, and that this default was a natural consequence of the sad vicissitudes of things. Long after, the "Countesse Dowager of Pernbroke," presumably distressed at this omission, set up the monument with a bust to the memory of the mentor to whom assuredly she owed much. It is a slight, but a picturesque and touching incident of her life, and worthy of her loyal character.

The bust bears no resemblance to the engraving from the picture in the possession of Lord Hothfield, or to another showing the poet at an earlier period of his life, prefixed to one of the editions of his works. It is a laureated head in white marble of a poet quelconque, accidentally, but fitly, much after the style of the bust of Tasso in his chamber in the Onofrio at Rome; it is doubtless from the chisel of John Stone. ${ }^{1}$

We pass from the poet to the pupil.

It is by no means surprising that so much should have been written in county histories, and in numerous historical and antiquarian works, concerning the renowned Anne Clifford. Her illustrious descent from two ancient and noble families, her own two distinguished alliances, her beauty, her popularity, her accomplishments, her strong sense, her intrepidity under adverse

1 With the same generous appreciation of genius, the Countess of Dor. set erected in 1620 the monument to Spenser in the Abbey, for which Stone t.ells us in his Note Book he was paid $\mathfrak{E 0}$; and in a similar spirit she put up in the same sanctuary the monument with a bust to Drayton, the opening sentence of the inscription being exactly similar to that on the memorial to Daniel, indicating that both com. positions are from Anne Clifford's pen.

The productions of the Stones (Nicholas, and his sons Henry-called "Old Stone," to distinguish him from his brothers-Nicholas and John) are almost invariably in white marble, and are numerous and unmistakable. Extracts from the Note Book of the father are given in Walpole's Anecdotes. A volume illustrating the works of these revivers of the monumental effigy in England would be a valuable contribution to the history of native art. Pro. file busts of the father and the two cons, superposed one upon another, are in St. Martin's Church, London.
Henri Stone was also a painter, and an excellent copier of Vandyck.

The laudable custom under which patrons and lovers of literature dedicated memorials to departed poets has often been exemplified. To give further instances, Nicholas Brigham set up in the Abbey, as a monument to Chaucer, in 1555 , one that the Dissolution had caused to be ejected from Grey Friars, and which originally commemorated Sir Walter Blount, K.G., died 1477 , or Lord Mountjoy, 1485. (See Archaological Journal, Vol. XXXVIII, p. 361; paper by M. H. Bloxam.) The monument and bust of Dryden was erected in the Abbey by Sheffield, Duke of Buckingham, in 1720 . The plaster bust at Canons Ashby, Northamptonshire, the picturesque seat of Sir Alfred Dryden, is doubtless a cast from the sculptured head of the famous old Westminster. His name is largely cut on one of the rude benches that stood in the Shell of Westminster School up to the time of the unhappy demolition of that classic feature in the old Benedictine dormitory. 
circumstances, and her final triumph over her enemies have contributed to illustrate a great character. The long period of more than thirty years of an unusually prolonged life, which were spent among her own people, restoring and beautifying, with singular antiquarian zeal, the castles and houses of her great inheritance, at last regained, and her many and enduring works of mercy, have alike combined to bring down and vividly carry on her fame to posterity; and after two centuries and a quarter her name still sounds as a trumpet blast in wide districts of the North. To have borne a part in the formation of so striking and masterful a character is no small tribute to the tact and teaching of Daniel.

Having regard to what has already been set down in so many printed books - most of them, however, difficult of access-concerning Anne Clifford, and bearing in mind that antiquarian dissertations, while naturally apt to err in being rather dry, the more often offend in being too long, it will be found convenient now to give only a rapid sketch of her career, dwelling more particularly upon the few circumstances or occasions on which the pupil and the poet were jointly or publicly concerned, and making use, as far as possible, of the illustrious lady's own Diary. ${ }^{1}$

The Lady Anne Clifford-“" Countesse Dowager of Pembroke, Dorsett, and Montgomery, sole daughter and heire

1 There are several MS. copies of the Diary, more or less full, and some with striking personal details, but complete copies seem to be difficult to get a sight of. Apparently the original of them all is the Sumarie and Memorial, dictated, corrected, and interlined by the Countess of Pembroke in 165\%. This record appears at the end of the third of the three volumes of documentary evidence at Sixipton Castle, collected by Margaret, Countess of Cumberland, for the prosecution of her daughter's rights to the inheritance of her ancestors, and thus compiled in 1649. There is also at Skipton Castle a small quarto MS. entitled, A True Memoriall of the Life of Lady Anne Clifford, \& c., consisting of an abstractof the three greatbooks, and a condensed account of the Life comprised in the third volume. This latter record has been printed at the end of the second of the York Volumes published by the Archrological Institute in 1846, transcribed and edited by “ E. H." For the general events of Anne Clifford's personal history the present writer is indebted to an articlo by Canon Raine in the Archoologia CEliana, 2, S., Vol. I, page 1, compiled from Atkinson's Worthies of Westmerland; Coleridge's Northern Worthies; Noble and Grainger's Biographical History of England; Gilpin On the Picturesque; Ballard's Memoirs of Illustrious Ladies; Nicholson and Burn's History of Westmerland, and Whitaker's Histories of Craven and of Whalley; and for particulars to the extracts from the Diary, given by $J$. $H$. Wiffen, the accomplished translator of Tasso, in his Historical Memoirs of the House of Russell, and in Nichols's Progresses of King James, rol. i. 
to the late right noble George Clifford, Earle of Cumberland, and by my birth from him Lady of the Honor of Skipton in Craven, Barronesse Clifford, Westmorland, and Vessey, and High Sheriffesse by inheritance of the county of Westmorland "- was born in Skipton Castle January 30 th, 1590, her father George, Earl of Cumberland, being: one of the most distinguished and reckless men of the time of Elizabeth, and her mother Margaret, youngest daughter of Francis Russell, second Earl of Bedford, and sister of the heroic William, Lord Russell of Thornhaugh."

Her two brothers died within sixteen months of her birth, and, disappointed in his hopes of an heir to carry on the name of Clifford, and living at great variance with his wife, the Earl of Cumberland, while his daughter was yet in her cradle, fine-barred his father's entail, settled his Westmoreland estates on his wife, by way of dowry, and all his other lands upon his brother Sir Francis Clifford, with remainder to his daughter only in default of male issue to Sir Francis. These unjust disposals were the source of long-continued and ruinous suits at law, which only ceased at the death of Henry, Earl of Cumberland, son of Earl Francis, in 1643 without heir male. With a great part of her life strenuously spent in struggling to regain her honest rights, and urged thereto by the untiring example of her mother, the development of Anne Clifford's masterful character is not surprising.

With regard to the introduction of Anne Clifford to the court the Diary may now speak for itself:-

"In $160 \frac{2}{3}$, at Christmas, I used to go much to the Court and some-

1 Thus she gives her styles and titles in her will, oddly interpolating the dignity of her first marriage between those of Herbert of the second, such being the chronological sequence of the three creations. The same order is observed on her coffin plate and on which Dorset, perbaps on account of his adrerse action in the long litigations, appears in smaller lettering than Pembroke and Montgomery.

- This eminent captain was present at the battle of Zutphen in 1586, and there soothed the last hours of Sir Philip Sidney, who bequeathed to him his best gilt armour, a chivalrous episode! He succeeded "that famous spirit " in the Governorship of Flushing, "the key of the Netherlands," and on

his recall in 1593 was constituted Lord Deputy of Ireland. He left an only child, Francis, who succeeded his cousin Edward as fourth Earl of Bedford in 1627, and will long be remembered as the "Wise Earl of Bedford" and the patriotic drainer of the Fens. On the north side of the tomb, with the effigy of Lord Russell, in Thornhaugh church, Northamptonshire, who died in 1613, are figures of his three sisters (his three brothers being on the south side). Anne, wife of the Earl of Warwick; Elizabeth, wife of the Earl of Bath ; and Margaret, wife of the Earl of Cumberland. They kneel before faldstools bearing their impaled arms, and wear jewelled cauls, ruffs, and scarlet mantles lined with ermıne. 
times did lie in my aunt of Warwick's chamber on a pallet, to whom I was much bound for her continual care and love of me ; in so much as if Queen Elizabeth had lived, she intended to have preferred me to be of the privy chamber; for at that time there were as much hope and expectation of me, both for my person and fortunes, as of any other young lady whatsoever. A little after the queen removed to Richmond, she began to grow sickly. My lady used to go often thither, and carry me with her in the coach; and using to wait in the cofferchamber, many times came home very late. About the 21st or 22nd of March, my aunt of Warwick sent my mother word, about nine o'clock at night, she lying then at Clerkenwell, that she should remove to Austin Friars, her house, for fear of some commotion, though God in his mercy did deliver us from it. Upon the 24.th, Mr. Hocknell, my aunt of Warwick's man, brought us word from his lady that the queen died about 2-3 in the morning: the message was delivered to my mother and me in the same chamber where afterwards I was married. About ten o'clock, King James was proclaimed in Cheapside with great joy and triumph, which triumph I went to see and hear.

"The peaceable coming in of the king was unexpected of all sorts of people. A little after this, Queen Elizabeth's corse came by night in a barge from Richmond to Whitehall, my mother and a great company of ladies attending it, where it continued a good while standing in the drawing chamber, and was watched all night by several lords and ladies; my mother sitting up with it two or three nights ; but my lady would not give me leave to watch, by reason I was held too young." (She had entered her fourteenth year two months before this date.)

"When the corse of Queen Elizabeth had continued at Whitehall as long as the council had thought fit, it was carried from thence with great solemnity to Westminster, the lords and ladies going on foot to attend it; my mother and my aunt of Warwick being mourners; but I was not allowed to be one, because I was not high enough, which did much trouble me then. But yet I stood in the church at Westminster to see the solemnits performed.

"A little after the queen's funeral my lady and a great deal of other compauy . . - went down with my aunt of Warwick to Northall, and from thence we all went to Theobalds to see the king, who used my mother and my aunt very graciously; but we all saw a great change between the fashion of the court as it was now and of it in the queen's time. Innumerable were the knights that were then made.

"All this early spring I had my health very well; my father used to come sometimes to us at Clerkenwell, but not often; for he had at this time, as it were, wholly left my mother."

The impressive circumstances under which the young girl Anne Clifford first made her acquaintance with the court will be noticed, as well as the proximity of Daniel's house in Old Street, St. Luke's, to that of the Countess of Cumberland at Clerkenwell, enabling the poet to continue with facility the supervision of his pupil's education. 
"About this time my aunt of Bath and her lord came to London, and brought with them my Lord Fitzwarren, and my cousin Frances Bourchier." They were joined near London by her cousin, the young Earl of Bedford, and his newly-married wife, the beautiful Lucy Harrington, by her uncle Sir William Russell-created Lord Russell of Thornhaugh July 21st-and many more. The Countess of Warwick and others went forward to meet the Queen in the Shires. The Countess of Cumberland and her daughter followed the next day. They killed three horses in the heat and hurry, and got as far as Lord Kent's house at Wrest. Finding it deserted with only a caretaker, they slept in the great hall and hasted away betimes in the morning, and came at night to Rockingliam Castle, where the Warwick party was rejoined. It was a long and hot journey on horseback for a child in her fourteenth year, but the ladies of the old court were eager to forestall the Council in the appointments in the new one. A few days later they all proceeded to Sir Thomas Griffin, at Dingley, near Leicester, as we have seen. Here they first met the Queen, "who kissed us all and used us kindly."

An excursion was made by the Cliffords from Dingley to Combe Abbey, near Coventry, to pay their respects to the Princess Elizabeth, who had gone there from Dingley under the charge of Lady Harrington, the chatelaine, and the Countess Kildare. Sleeping that night at Sir Richard Knightley's, at Fawsley, near Daintry, “* where my Lady Elizabeth Knightley made exceedingly much of us," they rested the next day in that secluded and pleasant place, and no doubt dined in the great hall and sat in the storied bay window, discussing the moving events of the time. Meanwhile the Queen and her train arrived on that morning at Holdenby House, the noble mansion built by Sir Christopher Hatton, and the whole cavalcade went on to Althorp, the seat of Sir Robert Spencer, in the cool of the day, Saturday, June 25 th. Anne Clifford and her mother and her "aunt of Warwick" attended the court at Althorp the next day, "which Sunday was kept with great solemnity," and here she met, for the first time, her cousin Henry, who eventually kept her so long out of her estates. 
On the greensward of Althorp Park a delightful masque by Ben Jonson was performed on Saturday by the sons and daughters of the county gentry, personating satyrs and fairies. In the course of the entertainment a rich jewel was giren to Anne of Denmark by Queen Mab, and a dog nam "d "Ringwood" to Prince Henry. The royal cortege lefi Althorp on Monday for Easton Neston, near Towcester, and having there joined that of the King, as we have seen, the great company proceeded to Grafton -an ancient royal house, then in the occupation of the Earl of Cumberland-and were sumptuously entertained. With his usual impetuosity the Earl of Cumberland "did ruil and course at the field, where he hurt Henry Alexander very dangerously." He wounded the Countess his wife still more deeply, for, as the Diary says, "At this lime of the king's being at Grafton my mother was there; but not held as mistress of the house, by reason of the difference between my lord and her which was grown to a great height." Thus Margaret, Countess of Cumberland was not suffered to take the head of her own table on so notable an occasion. From Grafton the court went to Salden House, Muresley, Buckinghamshire, and so to Windsor.

On July 2nd, at the Feast of St. George, on the installation of Prince Henry, Anne Clifford "stood with my Lady Elizabeth's grace in the shrine in the great hall, to see the king and all the knights sit at dinner. Thither came the archduke's ambassador, who was received by the king and queen in the great hall, where there was

1 On the morning of the Queen's departure from Althorp, a molris of clowns was introduced bv a speech written by Ben Jonson, and spoken by "Nobody," who thus alludes to Hatton :-

"They come to see and to be seen,

And though they dance before the Queen,

There's none of these doth hope to come by

Wealth to build another Holmby :

All these dancing days are done,

Men must now have more than one

Grace to build their fortunes on,

Else our soles would sure have gone

All by this time to our feet.-
I do not deny where Graces meet

In a man that quality

Is a graceful property :

But when dancing is his best,

Beshrew me I suspect the rest."'

It was quite clear that Queen Elizabeth was dead!

An octagonal font in Holdenby church was painted in the time of Sir Christopher Hatton, with seven impaled coats showing the marriages of as many generations of Holdenibys, the last being the alliance of the heiress of Holdenby with Hatton, grandfather of sir Christopher. This interesting record was abolished when the church was "restored" in 1867. 
such an infinite company of lords and ladies, and so great a court, as I think I shall never see the like. At Windsor, there was such an infinite number of ladies sworn of the queen's privy chamber, as made the place of no esteem or credit. Once I spake to my lady of Bedford to be one, but had the good fortune to miss it." At the Coronation, her father and mother both attended in their robes_- "which solemn sight my cousin Frances stood to see, though she had no robes, and went not amongsi the company; but my mother wonld not let me see it, because the plague was so hot in London."

Anne Clifford took no part in Daniei's Vision of the Ticelve Goddesses, performed, as we have seen, by the Queen and eleven of her ladies; indeed, she tells us that although "in my youth I was much in the court with her, and in masques attended, I never served her."

It has been suggested above that Daniel became tutor to Anne Clifford in the year 1596 . It is probable that his direction of her studies was not entirely broken oft when she took her place at the court in 1603. The poet's owu position there would have enabled a general direction and supervision of his noble pupil's training to be still carried on, and it is likely enough that this did not cease until her marriage in February, 1610, when she had just entered her twenty-first year.

On October 30th, 1605, George, Earl of Cumberland died, being finally reconciled with his long-suffering wife. His daughter saw him for the last time "in the open air" on Greenwich Heath, September 1st. So passed away at the early age of forty-seven a very striking and popular public figure. Excelling in the accomplishments of the courtier and in the ancient exercises of chivalry, then fast dying out, and famous as a fighting man by land, he was yet more so at sea. He furnished, at ruinous expense to his estate, a series of naval expeditions, and with undaunted patriotism constantly urged his relentless sword against the Spaniard. On the other hand, his prodigality impoverished for a time his great estate, and his profligacy brought affliction upon his wife, while the disposition of his lands entailed upon her and upon his only child and rightful heir a course of harassing legal suits which continued during many weary years. 
At the end of a vivid description which Anne Clifford gives in the "memorables of myself which I have caused to be written " of her appearance at the age of eighteen, ${ }^{1}$ she thus alludes to her education-" And my mother did with singular care and tenderness of aflection educate me, as her most òear and only daughter, seasoning my youth with the grounds of true religion and moral virtue, and all other qualities befitting my birth. In which she employed, as her chief agent, Mr. Samuel Daniel, that religious and honest poet, who composed " the Civil Wars of England between the two Houses of York and Lancaster,' and also writ many other treatises both in prose and verse. I was not admitted to learn any language, because my father would not permit it; but for all other knowledge fit for my sex, none was bred up to greater perfection than myself." 2 A more genuine testimony to the poet's worth there could not be.

Anne Clifford married on February 27th, 1610, Richard Sackville, Lord Buckhurst, heir apparent of the Earl of Dorset, who succeeded his father two days later. By him she had three sons, who died young, and two daughters, who married, the one John, Lord Tufton, Earl of Thanet, and the other James Compton, Earl of Northampton. Lord Dorset died March 28th, 1624.

On January 14th, 1608, she took part in Jonson's Masque of Beauty at Whitehall, and was one of the "Celebraters" in his Masque of Queens, February 2nd, 1609. On June 5 th, 1610, the part allotted by Daniel to the Countess of Dorset in his masque of Tethys's Festival, or "The Queen's Wake," was the Nymph of Aire, the river that runs near

1 She speaks of her eres black like her father's, and quick and lively like her mother's; her very long and thick brown hair, her "exquisite shape of body," her memory, judgment and discernment.

- Irer range of information was so extensive that Dr. Donne said she could talk on any subject from predestination to slea silk.

It may reasonably be assumed that Daniel was for a time domiciled in the house of the Earl of Cumber. land. It will be remembered that Andrew Marvell was tutor ts Mary, duughter of the great Lord Fairfax, who afterwards became Duchess of
Buckingham. Spenser was receired into the household of the Earl of Leicester. Butler, the most daring and felicitous of wits, lived successively in the families of Mr. Jefferies, the Countess of Kent, and Sir Samuel Luke. Locke, an old Westminster, lired for many years with his friend Sir Francis Masham, and died in his house. It is not generally known that the reading of Locke was first introduced into Cambridge by Charles Kidman, for many rears fellow and tutor of Bene't College, who died in 1740. Swift spent eleren years, in three periods, eating his proud heart out in the family of Sir William 'Temple. 
Skipton Castle, where she was born. Delightful as the whole "glorious masque" was, the most interesting scenes were those in which the youthful Duke of York appeared as Zephyr, in a robe of green satin, embroidered with golden flowers, wearing silver wings, and crowned with a floral chaplet of many colours, and attended by eight little naiads. Zephyr, supported by two Tritons, presented costly gifts to the King and to Prince Henry - namely, a golden trident to the sovereign, then, as now, hailed as "Monarch of the Ocean," and a richly jewelled sword to Prince Henry, in honour of whose creation as Prince of Wales this festival was ordained. Important features of the masque proper were the dances performed by Anne of Denmark as Tethys, "Queen of the Ocean," and her thirteen ladies as nymphs of the rivers, in a most brilliant scene and with appropriate dresses, designed and minutely described by the "Archetictor" Inigo Jones, and their subsequent measures, corantos, and galliards with the lords of the court.

In the conclusion of the ante-masque Prince Charles and the eight sylph-like naiads, of his own age and height, in the palest blue satin, embroidered with silver flowers, "their seemely hayre downe-trailing on their shoulders," danced an intricate ballet, the figures so contrived that the princely Zephyr was always encircled by the fair children. Thirty-eight years later, when Charles Stuart stood upon the brink of the grave-the most lonely, and pathetic, and perhaps the guiltiest figure of English history, declaring, with the true spirit of his race, that he feared not death. that he had " a just cause, and a righteous judge"-did memory recall these innocent and fairy-like scenes of his childhood?

The lamentable death of Prince Henry in 1612, farreaching in its consequences, changed the whole course of English history. The Earl of Dorset walked at the funeral, with eleven others of his rank, as assistants to the chief mourner, Prince Charles. Neither the King nor the Queen were present.

In 1613 the Countess of Dorset went with the Queen on her progress to Bath, and on April 2nd, 1616, she took her last leave of her "dear and blessed mother" in the 
open air near Brougham Castle, and where she subsequently set up a pillar of stone, which still remains. The Dowager of Cumberland died in Brougham Castle May 24th, 1616, and was buried in the church of St. Laurence at Appleby. ${ }^{1}$ Now the Westmoreland estates, the dowry lands, by the will of Earl George passed to Francis, Earl of Cumberland, and the personal connection of the Countess of Dorset with her ancestral lands was quite cut off.

Thus it fell to the daughter to continue alone the long litigation which her mother in her behalf had so persistently but unsuccessfully carried on, the object having been to wrest from Francis, Earl of Cumberland the lands that his brother had settled on him. Anne Clifford's difficulty was increased by the continued opposition of the King and the adverse action of the Earl of Dorset.

She married secondly, 1630, Philip Herbert, K.G., Earl of Pembroke and Montgomery, one of the greatest noblemen of the kingdom, who had succeeded his brother William three months before. He died in 1655 .

It will not be in accord with the compass of the present account to touch at all upon the details of the legal transactions in which Margaret, Countess of Cumberland and her daughter were so long and with so much determination engaged. Suffice it to say that Time brought the relief which Law was powerless to grant. In 1640 Francis, Earl of Cumberland died, and three years later, namely in December, 1643, his son Henry, fifth and last Earl of Cumberland, succumbed to a burning fever, leaving no issue male. Consequently all the ancient lands of her family reverted to the Countess of Pembroke. Her reinstatement in her ancestral estates, from which she had been so long and so unjustly interdicted by her father's will, and the noble use she made of her fortune, form a romantic and chivalric narrative almost surprising enough for an Oriental tale by Shehazarade.

\footnotetext{
1 For an account of the tombs of Margaret, Countess of Cumberland, and the Countess of Pembroke, Dorset, and Montgomery, see Transactions of the
}

Cumberland and Westmorland Antiquarian and Archaological Societ.u, rol. for 1885 , p. 174 , article by R. S. Ferguson. 
And although the story of Anne Clifford's buildings, and restorations, and charitable deeds has often been recounted, the present notice of her tutor and his pupil would be incomplete without once more recalling that on regaining her great domains she made it her business to restore and beautify her castles and houses, dismantled or "slighted" during the Civil War, or earlier; her duty to increase or rebuild the churches in which she had interest; while she found her greatest pleasure in the exercise of true hospitality in her own country, for which she had so great an affection.

Thus the castles of Skipton, Brougham, Appleby, Brough on Stane mere, Pendragon-the Vetripont stronghold, which had lain waste ever since 1341-and Barden Tower were put in order, made habitable, and hospitably dwelt in by herself from time to time. Brougham Hall she bought. The rebuilding or additions to the churches of Appleby, Skipton, Bradgate, Brougham, Nine Kirks, and Mallerstang testify to her religious zeal, the results of the teaching of Daniel, while almshouses, bridges, and other works of public benefit evince her open-handed and wise generosity. She set up a tomb in Skipton church to the father who wronged her, one with an effigy to her mother in Appleby church, and there, like an orderly person, she made her own vault in 1655 , where she now lies.

Anne Clifford, Countess of Pembroke, Dorset, and Montgomery, died in Brougham Castle March 22nd, 1675, in her eighty-seventh year, and was succeeded by her grandson, Thomas, Earl of Thanet-eldest son of her elder daughter, Margaret Sackville, one of the co-heirs of her first husband, Richard, Earl of Dorset-whose direct line has only come to an end in our own day.

*** The writer has pleasure in expressing his obligation to his old friend Chancellor Ferguson for references to books and for other assistance most kindly given. 


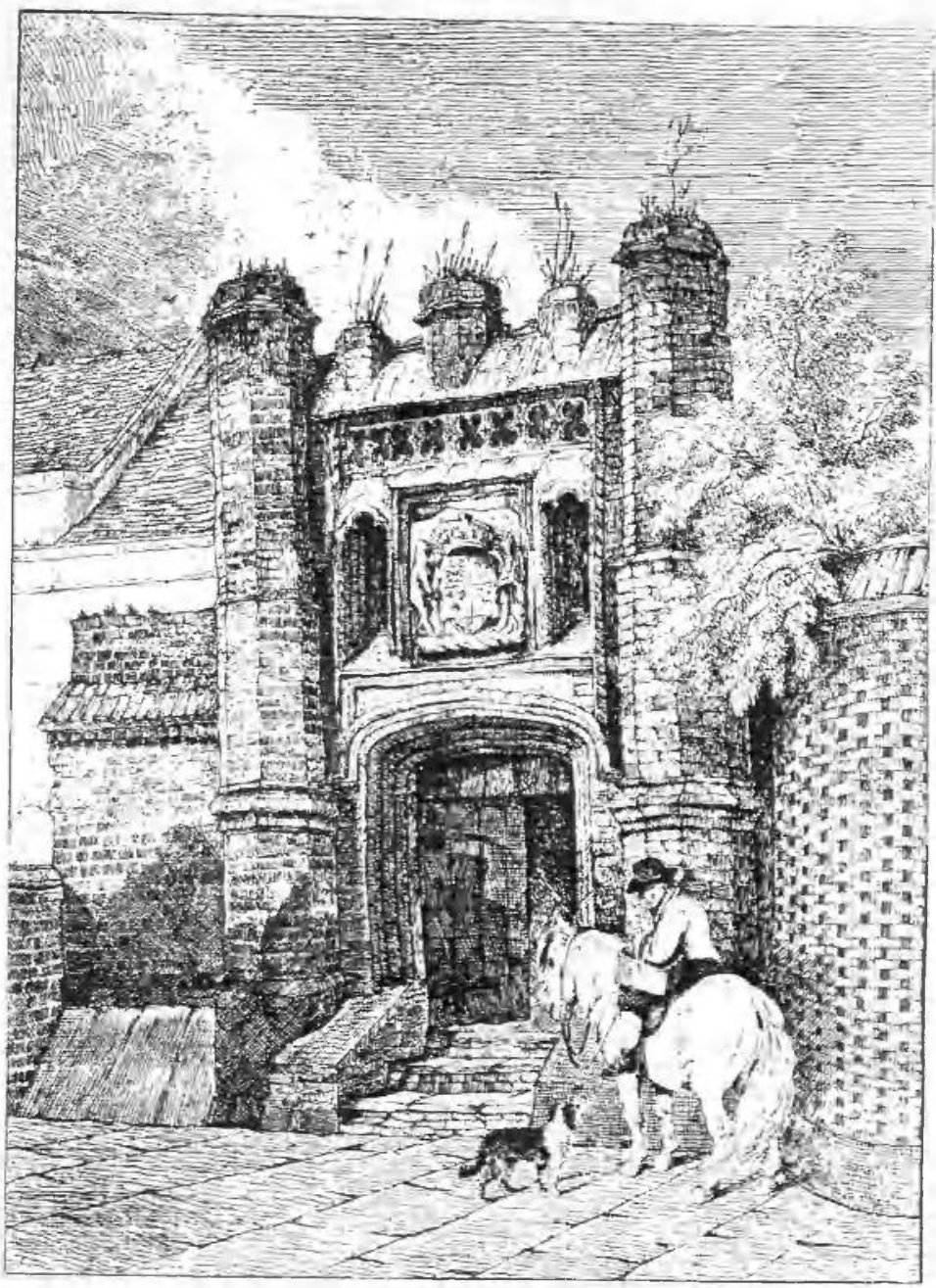

No. 1.-GATEWAY TO WOLSEY'S COLLEGE, IPSWICH.

(Showing coping of wall on the left.)

By permission of Mr. W. E. Harrison. 
To face plate 3 .

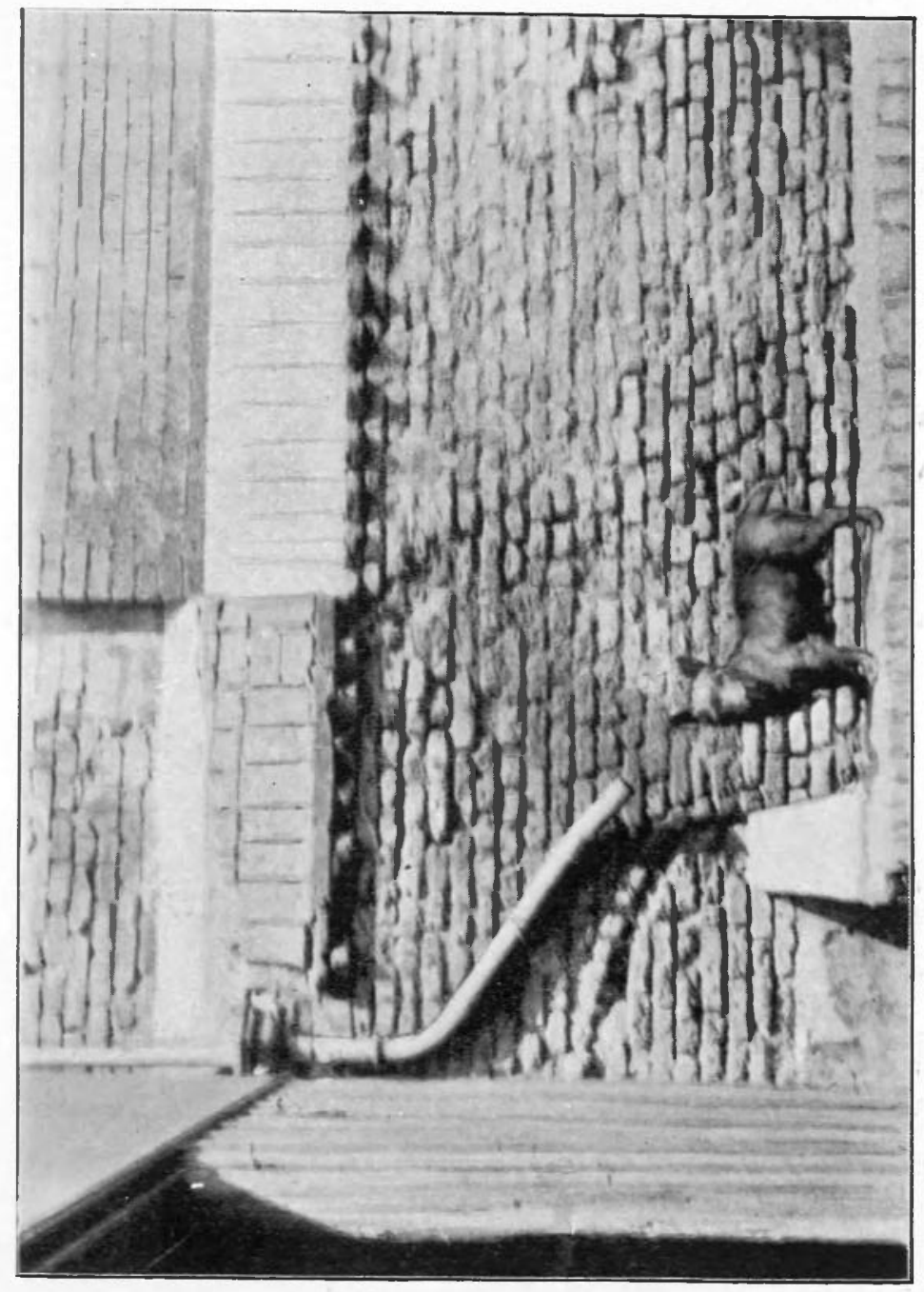

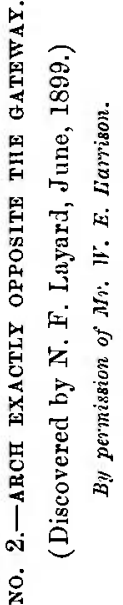


To face plate 2 .

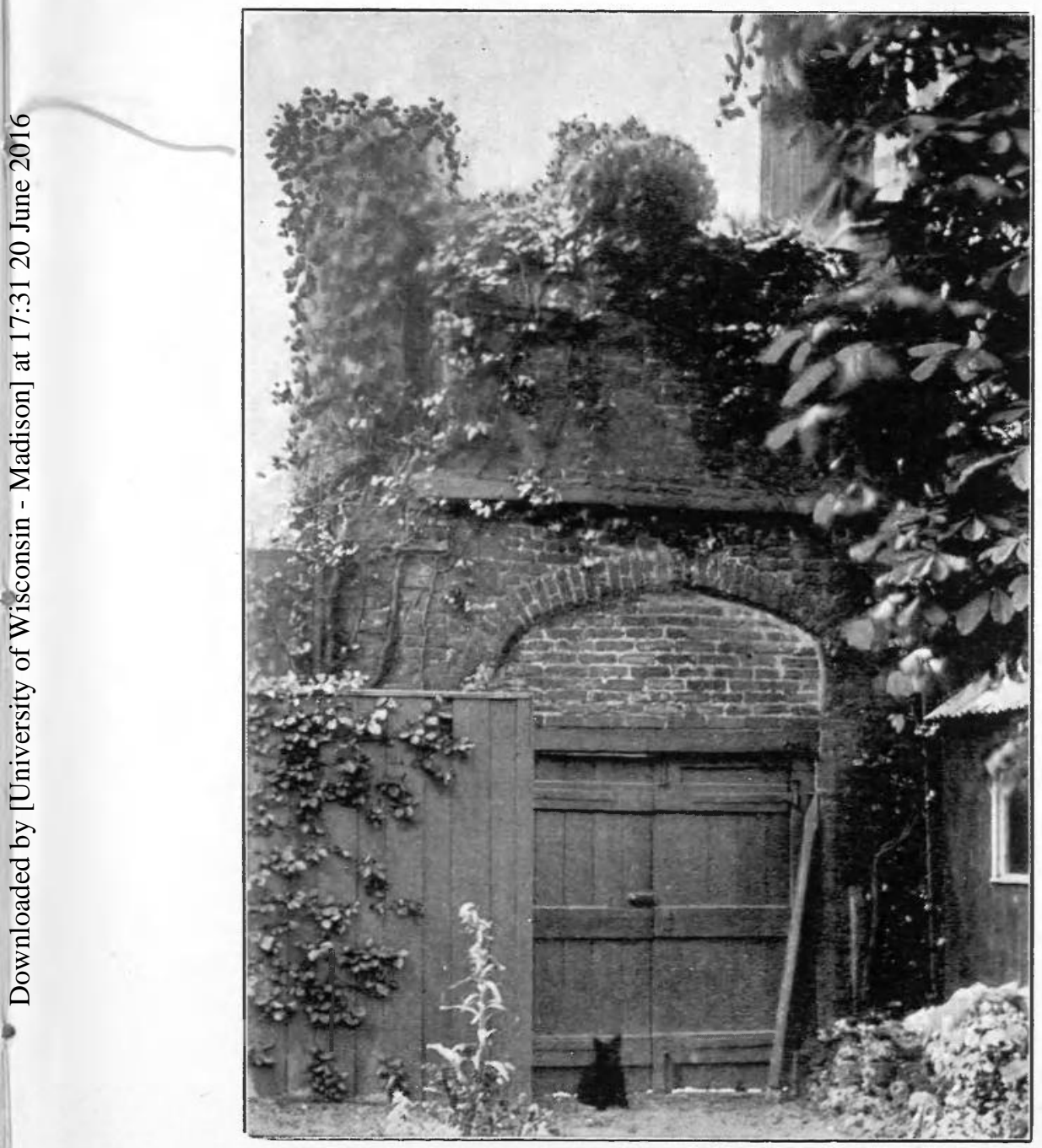

NO. 3.-INTERIOR OF GATHWAY OF WOLSEY's COLLEGE SHOWING THE ARCH. Fy pcrmission of $\mathrm{Mr}: \mathrm{E}$ W. E. Harriscn. 